\title{
У Korona, koti ja kontrolli: väkivaltatyöntekijöiden näkemyksiä lähisuhdeväkivallan kohteina olleiden avun saamisen haasteista korona-aikana
}

Lähisuhdeväkivalta on maailmanlaajuinen vakava sosiaalinen ja terveydellinen ongelma sekä ihmisoikeuskysymys. Tutkimukset osoittavat, että läheisissä suhteissa tapahtuva väkivalta on tyypillisesti lisääntynyt yhteiskunnallisten kriisien, kuten pandemioiden ja luonnonkatastrofien yhteydessä. Suositukset ja rajoitukset sosiaalisten kontaktien välttämiseen ovat olleet perusteltuja koronaviruksen leviämisen estämisessä. Lähisuhdeväkivallan kokijat kotiin eristäytyminen on kuitenkin saattanut aiempaa haavoittuvampaan asemaan.

Artikkelissa jäsennetään väkivaltatyöntekijöiden näkemyksiä lähisuhdeväkivaltaa kokeneiden avun saamisen haasteista ja kysytään, miten turvakodeista ja väkivaltatyön avopalveluista lähisuhdeväkivaltaan apua hakeneiden tilanne ja palvelujen saatavuus on korona-aikana muuttunut. Empiirisenä aineistona käytetään turvakodeista korona-aikana kerättyjä seurantakyselyjä sekä turvakotien ja väkivaltatyön avopalvelujen työntekijöiden fokusryhmähaastatteluja. Laadullisen tutkimuksen analyysimenetelmänä hyödynnetään temaattista sisällönanalyysia. Tulokset osoittavat, että kotiin eristäytyminen korona-aikana on mahdollistanut ja tehnyt näkyväksi pakottavan kontrollin ja vallankäytön tapoja, jotka ovat vaikeuttaneet lähisuhdeväkivaltaa kokeneiden avun hakemista ja vastaanottamista. Esimerkiksi digitaalisen ja taloudellisen väkivallan muodot ovat nousseet aiempaa vahvemmin esille asiakastyössä. Myös lasten määrän väheneminen turvakodeissa, lasten katoaminen väkivaltatyön piiristä ja haavoittuvien ryhmien, kuten ulkomaalaistaustaisten palvelujen piiriin pääseminen ovat herättäneet huolta ammattilaisten keskuudessa. Korona-ajan arjen ja työn käytäntöjen muutokset sekä pandemiaan liittyvät uhat ja pelot asettavat haasteita väkivaltatyölle ja palvelujärjestelmälle. Tieto siitä, miten koronatilanne vaikuttaa avun hakemiseen, tarjoamiseen ja vastaanottamiseen on tärkeää väkivaltainterventioiden kohdentamiseksi ja tuen ja palveluiden saatavuuden turvaamiseksi.

ASIASANAT: Korona, lähisuhdeväkivalta, palvelujärjestelmä, väkivaltatyö MARITA HUSSO, ELLI HYVÄRI, ANNIINA KAITTILA, JOHANNA HIETAMÄKI, ANU KARHINEN-SOPPI, OUTI KEKKONEN, JARNO TUOMINEN 


\section{YDINASIAT}

- Kotona tapahtuva naisiin ja lapsiin kohdistuva väkivalta on korona-ajan varjopandemia.

- Väkivallan tunnistamisessa, kirjaamisessa ja väkivaltaan puuttumisessa on palvelujärjestelmässä puutteita.

- Kotiin eristäytymisen mahdollistama pakottava kontrolli on vaikeuttanut avun hakemista ja tehnyt näkyväksi digitaalisen ja taloudellisen väkivallan muotoja.

- Lapset ja muut haavoittuvat ryhmät ovat jääneet palveluiden katveeseen.

- Väkivaltaan puuttuminen edellyttää koulutusta, koordinointia ja palvelujärjestelmän kehittämistä.

\section{JOHDANTO}

Lähisuhteissa tapahtuva väkivalta on maailmanlaajuinen vakava sosiaalinen ja terveydellinen ongelma sekä ihmisoikeuskysymys. Se aiheuttaa merkittävää inhimillistä kärsimystä sekä huomattavia kustannuksia yhteiskunnalle (1-3). Väkivalta on syvästi hyvinvointia horjuttava kokemus ja sen seuraukset ovat vakavia ja pitkäkestoisia. Aiemmat tutkimukset osoittavat, että lähisuhdeväkivalta on tyypillisesti lisääntynyt yhteiskunnallisten katastrofien, kuten hurrikaanien ja pandemioiden yhteydessä (4-8). Erityisesti naisiin kohdistuvan parisuhdeväkivallan ja lasten kokeman väkivallan on monissa maissa raportoitu lisääntyneen ja pahentuneen koronapandemian aikana (9-15).

YK on nimennyt kotona tapahtuvan ja naisiin kohdistuvan väkivallan koronaviruksen varjopandemiaksi (16). Naiset kokevat tyypillisimmin väkivaltaa kotona, yksityisissä tiloissa ja työpaikoilla. Yhä enemmän häirintää ja väkivaltaa esiintyy myös verkossa. (17). EU:n laajuisen kyselytutkimuksen mukaan $30 \%$ suomalaisista naisista ja yli 15 -vuotiaista tytöistä on kokenut fyysistä ja/tai seksuaalista väkivaltaa, mikä on eurooppalaista keskiarvoa (20\%) selvästi korkeampi luku (18). Tilastokeskuksen julkaiseman Rikos- ja pakkokeinotilaston mukaan vuonna 2019 viranomaisten tietoon tulleissa pari- ja lähisuhdeväkivaltarikoksissa oli 10600 uhria, joista 7900 oli aikuisia. Aikuisiin kohdistuneesta perhe- ja lähisuhdeväkivallasta puolet tapauksista oli avio- tai avopuolisoiden välistä väkivaltaa. Avio- ja avopuolisoiden sekä entisten avio- ja avopuolisoiden välisessä väkivallassa uh- ri oli nainen hieman yli 80 prosentissa tapauksista. Toistuvan väkivallan uhreja oli 1500 . Heistä yli 90 prosenttia oli naisia. Alaikäisiä oli 24,6 prosenttia uhreista. Vanhempien lapsiinsa kohdistamaa väkivaltaa raportoitiin 2600 tapausta vuonna 2019 , mikä on 24,3 prosenttia tietoon tulleesta perhe- ja lähisuhdeväkivallasta. (19.)

Apua väkivaltaan liittyviin ongelmiin ja oireisiin haetaan pääasiassa sosiaali- ja terveydenhuollosta (20-21). Nämä tahot ovat siten avainasemassa väkivallan tunnistamisessa ja siihen puuttumisessa. Väkivalta jää kuitenkin usein ammattilaisilta tunnistamatta ja raportoimatta. Yhteiskunnallisesti erityisen vakava palvelujärjestelmän ongelma on siten se, että väkivaltaan ei puututa, vaan sen annetaan jatkua.

Toistaiseksi on varsin vähän tietoa siitä, miten korona ja siihen liittyvät suositukset ovat vaikuttaneet lähisuhdevaltaa kokeneiden tilanteeseen ja palveluihin. Väkivallan kohtaamisen haasteita, ammatillisia käytäntöjä ja palvelujärjestelmää koskevat tutkimukset osoittavat, että keskeisenä ongelmana väkivallan tunnistamisessa ja siihen puuttumisessa ovat lähisuhdeväkivaltaan liittyvät asenteet ja väkivallan kieltämisen ja sivuuttamisen mahdollistavat käytännöt. Erityisesti naisiin kohdistuvaan parisuhdeväkivaltaan liittyy edelleen runsaasti uskomuksia väkivaltaa kokeneiden syyllisyydestä väkivallan kohteeksi joutumisestaan. (17, 22-26.) Vaikka väkivaltatyötä ja palvelujärjestelmää on 2000-luvulla kehitetty, väkivallasta kysymisessä, väkivallan tunnistamisessa, väkivaltaan liittyvien tapahtumien kirjaamisessa ja väkivaltaan puuttumisessa on palvelujärjestelmässä edelleen puutteita (2628). Tällä on merkittäviä vaikutuksia sekä avun hakemiseen ja saamiseen että tuen ja palvelujen järjestämiseen.

Tässä artikkelissa jäsennämme väkivaltatyöntekijöiden näkemyksiä lähisuhdeväkivaltaa kokeneiden avun hakemisen ja saamisen haasteista korona-aikana. Kysymme, miten koronapandemia on näkynyt turvakodeissa ja väkivaltatyön avopalveluissa. Empiirisenä aineistona käytämme turvakodeille viikkoraportteina toteutettuja kyselyjä sekä turvakotien ja väkivaltatyön avopalvelujen työntekijöiden fokusryhmähaastatteluja. Valtaosa turvakodeissa ja väkivaltatyön avopalveluissa kohdattavasta väkivallasta on naisiin kohdistuvaa parisuhdeväkivaltaa ja väkivalta on hyvin monella tavalla ja tasolla sukupuo- 
listunut ilmiö. Kyselyn avovastauksissa ja haastatteluaineistossa puhutaan kuitenkin runsaasti lapsiperheistä ja lapsista, ja käsitellään sukupuolen lisäksi esimerkiksi ikään, luokkaan ja etnisiin taustoihin liittyviä intersektionaalisia eroja sekä erilaisia suhteita ja väkivallan muotoja. Käytämme artikkelissa tästä syystä käsitettä lähisuhdeväkivalta, joka kattaa nykyiseen tai entiseen kumppaniin, lapseen, lähisukulaiseen tai muuhun läheiseen kohdistuvan väkivallan (29).

\section{TURVAKODIT JA VÄKIVALTATYÖN AVOPALVELUT LÄHISUHDEVÁKIVALTAA KOKENEILLE}

Turvakotipalvelut ja väkivaltatyön avopalvelut on tarkoitettu kaikille lähisuhdeväkivaltaa tai sen uhkaa kokeneille. Ne tarjoavat akuuttiin tilanteeseen ammatillista tukea, neuvontaa ja ohjausta. Väkivaltatyö oli Suomessa pitkään projektirahoituksella toimivien järjestöjen varassa. Tästä on seurannut paitsi suuria alueellisia eroja, myös sattumanvaraisuutta ja aukkoja palveluiden saatavuuteen, mikä on määräaikaisten projektirahoitusten varaan rakentuvan toiminnan yleinen ongelma (26). Tilanne on kuitenkin kohentunut Istanbulin sopimuksen ratifioinnin (1.8.2015) jäl- keen. Sosiaalihuoltolain muutokset (1301/2014) edellyttävät, että kunnat järjestävät tarvittavia sosiaalipalveluja lähisuhdeväkivaltaa kokeneille. Uuden turvakotilain (30) myötä turvakotien rahoitus siirtyi valtion vastuulle ja palveluista tuli asiakkaille maksuttomia. Myös lähisuhdeväkivaltaa koskeva lainsäädäntö on muuttunut. Vuodesta 2011 alkaen myös lievä pahoinpitely lähisuhteessa on ollut virallisen syytteen alainen rikos.

Lainsäädäntöjen muutokset näkyvät turvakotien työssä ja väkivaltatyön avopalveluissa. Turvakotien asiakasmäärät ovat kasvaneet 75 prosenttia vuodesta 2015 vuoteen 2019 (31). Avopalveluiden asiakasmäärä on kasvanut vuodessa lähes tuhannella, ja chateissä asiakasmäärä on viisinkertaistunut (32). Koronapandemian alkuvaiheessa turvakotien asiakasmäärä kuitenkin väheni alkuvuoteen verrattuna enimmillään lähes $30 \%$. Ennen korona-aikaa noin puolet turvakodin asiakkaista oli aikuisia ja puolet lapsia. Korona-aikana vuonna 2020 aikuisten määrä kasvoi edelleen verrattuna edellisiin vuosiin. Lasten määrä turvakodeissa sen sijaan väheni oleellisesti (33).

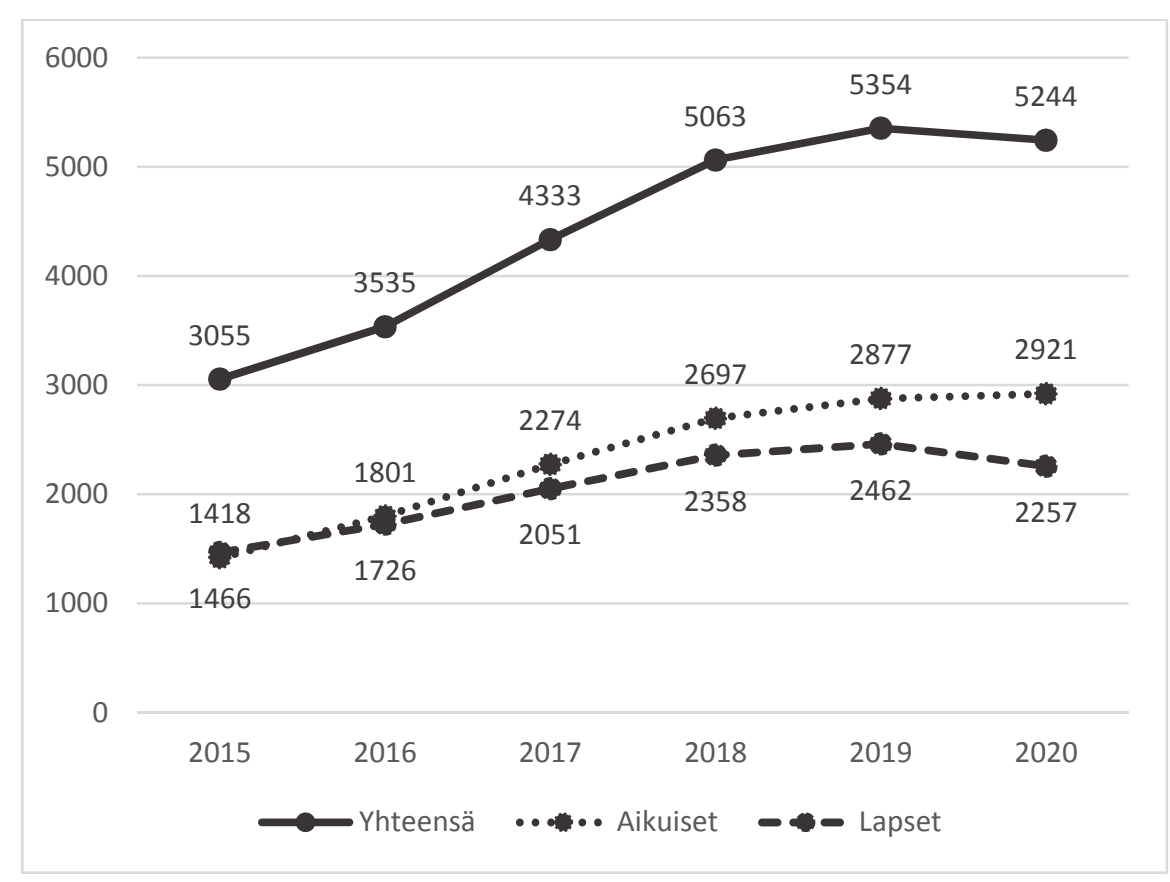

Kuvio 1. Turvakotien asiakasmäärä on noussut vuodesta 2015 alkaen vuoteen 2019 asti. Vuonna 2020 asiakasmäärä laski ensimmäistä kertaa. Asiakasmäärän pieneneminen koskee erityisesti lapsiperheitä, ja näkyy lasten määrän vähenemisenä turvakotipalveluissa. Lähde: Turvakotipalvelut 2020. (34). 
Syitä lapsiperheiden ja erityisesti lapsiasiakkaiden vähenemiselle yhtä aikaa kotona tapahtuvan väkivallan lisääntymisen kanssa on useita. Turvakoteihin ja väkivaltatyön avopalveluihin hakeudutaan paljolti sosiaali- ja terveyspalvelujen kautta. Esimerkiksi vuonna 2019 joka kolmas asiakas tuli Suomessa turvakotiin sosiaalipalveluiden ohjaamana (34). Korona-aikana kasvokkaiset asiakaskontaktit ovat vähentyneet, mikä on voinut vaikuttaa myös väkivallan puheeksi ottamiseen ja asiakkaiden turvakotiin ja väkivaltatyön avopalveluihin ohjaamiseen.

Avun hakemisen haasteita pohdittaessa unohtuu helposti, että väkivalta haavoittaa ja vaikuttaa kokonaisvaltaisesti lähisuhdeväkivaltaa kokeneiden elämään ja toimintamahdollisuuksiin. Merkittävä avun hakemisen ja väkivaltaisesta suhteesta irtautumisen este on pelko väkivallan lisääntymisestä eron yhteydessä. Myös yksinäisyys parisuhteen päättymisen jälkeen pelottaa ja ahdistaa monia. Yksinäisyyden kokemusta vahvistavat kotiin eristäytyminen, kotona tapahtuvan väkivallan häpeäminen sekä läheisen ihmisen tekemän väkivallan lamaannuttavat ja toimintaa rajoittavat vaikutukset. Lisäksi väkivallan normalisoituminen osaksi arkea, väkivaltaongelman torjuminen sekä naisiin kohdistuvassa parisuhdeväkivallassa yleinen uhrin syyllistämisen perinne ylläpitävät yhteiskunnallisia käytäntöjä ja asenteita, jotka estävät avun hakemista ja saamista kotona ja läheisissä suhteissa tapahtuvaan vakivaltaan (35-36.)

Koronapandemia on lisännyt avun hakemisen ja saamisen haasteita (37-40). Muutokset sosiaali- ja terveyspalveluiden saatavuudessa ovat voineet johtaa turvakoteihin tehtävän palveluohjauksen vähenemiseen. Pelko koronan tarttumisesta itseen tai lapsiin, vastuu omaisten asioiden hoidosta ja huoli läheisten pärjäämisestä ovat saattaneet estää avun hakemista kotona tapahtuvaan väkivaltaan (41). Myös taloudellisen epävarmuuden lisääntyminen ja kotona kumppanin ja perheen kanssa vietetyn ajan mahdollistama vallankäyttö ja pakottava kontrolli (coercive control), jolla pyritään rajoittamaan ja kontrolloimaan väkivallan kohteiden elämää, ovat voineet estää avun hakemista ja vastaanottamista (42). Turvallisuuden nimissä suositeltu kotiin eristäytyminen kumppanin tai perheen kanssa on siten lisännyt mahdollisuuksia kontrolloida ja valvoa puolison ja lasten tekemisiä, kuten esi- merkiksi internetin ja puhelimen käyttöä sekä liikkumista kodin ulkopuolella.

Yhteiskunnalliset suositukset ja rajoitukset sosiaalisten kontaktien välttämiseen ja kotona pysymiseen ovat olleet tehokkaita koronapandemian leviämisen rajoittamisessa. Lähisuhdeväkivaltaa kokeneiden avun hakemiselle ja palvelujen tuottamiselle ulkopuolisten kontaktien välttäminen ja kotiin eristäytyminen on kuitenkin tuonut lisää haasteita.

\section{TUTKIMUSTEHTÄVÄ JA MENETELMÄT}

Tutkimus on toteutettu Terveyden ja hyvinvoinnin laitoksen, Tampereen yliopiston ja Turun yliopiston "Koronaepidemian vaikutukset lähisuhdeväkivallan kokemuksiin ja palveluiden käyttöön (KOVÄ)” -tutkimushankkeessa. Tehtävänä on tarkastella koronapandemian ja siihen liittyvien rajoitustoimien vaikutuksia lähisuhdeväkivaltaan, avun hakemiseen ja palveluiden saatavuuteen. Artikkelissa jäsennämme työntekijöiden näkemyksiä lähisuhdeväkivaltaa kokeneiden avun saamisen haasteista korona-aikana. Kysymme, miten koronapandemia on näkynyt väkivaltatyön arjessa ja käytännöissä turvakodeissa ja väkivaltatyön avopalveluissa.

Artikkelissa hyödynnämme kahta erillistä turvakotien ja väkivaltatyön avopalveluiden työntekijöiltä kerättyä aineistoa. Ensimmäisenä aineistona on seurantatiedonkeruuna aikavälillä 23.3.2020-21.12.2020 toteutettu kysely, johon osallistuivat kaikki Suomen 29 turvakotia. Kysely toteutettiin yhteensä 23 kertaa ja siihen vastasivat turvakotien työntekijät. Seurantakyselyn vastausprosentti oli keskimäärin $82 \%$ (vaihtelu 62-100\%). Kyselyssä kartoitettiin työntekijöiden näkemyksiä koronapandemian vaikutuksista turvakotityön käytäntöihin sekä lähisuhdeväkivaltaa kokeneiden palveluihin. Kyselyaineisto on numeroitu ja aineistosta on poistettu tunnistetiedot, kuten turvakotien nimet ja paikkakunnat. Aineistositaateissa TK viittaa numeerisesti täsmennettyyn turvakotiin ja päivämäärä kertoo ajankohdan, jolloin turvakodista on vastattu kyselyyn.

Toisena aineistona on kahdeksan turvakodeissa ja väkivaltatyön avopalveluissa työskentelevien väkivaltatyön ammattilaisten fokusryhmähaastattelua. Viidessä haastattelussa oli mukana turvakotityöntekijöitä neljältä eri paikkakunnalta. Kolmesta eri kaupungeissa sijaitsevasta avo- 
palvelupaikasta kaksi edustaa Ensi- ja turvakotien liiton jäsenyhdistysten tarjoamaa tukea perhe- ja lähisuhdeväkivallan aiheuttaman tilanteen ratkaisemiseen sekä kriisistä selviytymiseen ja yksi kuuluu valtakunnalliseen kriisikeskusverkostoon. Ryhmähaastatteluihin osallistui kerrallaan kaksi tutkijaa ja 2-5 työntekijää ( $\mathrm{N}=27)$. Fokusryhmähaastattelut ovat tutkijoiden ohjaamia ja ylläpitämiä, tiettyyn aiheeseen fokusoituvia ryhmäkeskusteluja (43). Fokusryhmäkeskustelujen yleinen käyttötapa on osallistujien kokemusten, mielipiteiden ja käsitysten selvittäminen keskustelun kohteena olevasta ilmiöstä (44-45).

Fokusryhmähaastatteluihin osallistuneiden työkokemusten pituudet vaihtelivat vuodesta kolmeenkymmeneen vuoteen. Teemahaastattelurunkoon pohjautuvat keskustelut kestivät keskimäärin 1,5 tuntia ja ne nauhoitettiin äänitallenteiksi sekä litteroitiin sanatarkasti. Haastatteluissa käsiteltiin kokemuksia turvakotityöstä ja koronaajan mukanaan tuomista muutoksista, asiakkaiden tilanteesta ja turvakotien työkäytännöistä, toimintamahdollisuuksista ja haasteista kuluneena vuonna ja korona-aikana. Tutkimuseettisistä syistä poistimme haastattelusitaateista fokusryhmiin ja haastateltaviin viittaavat tunnistetiedot. Aineistositaattien merkinnöissä $\mathrm{R}$ viittaa ryhmään, $\mathrm{O}$ osallistujaan ja T tutkijaan.

Tutkimuksen toteutukseen saatiin puoltava lausunto THL:n tutkimuseettiseltä toimikunnalta syksyllä 2020. Tutkimuslupa ammattilaisille tehtyjen fokusryhmähaastattelujen toteutukseen saatiin turvakodeista ja lähisuhdeväkivallan avopalveluita koskevista yksiköistä. Tutkimukseen osallistuvia tiedotettiin etukäteen tutkimuksen toteutuksesta, osallistumisen vapaaehtoisuudesta ja luottamuksellisuudesta, ja heiltä kysyttiin suostumus tutkimukseen osallistumiseen.

Aineiston analyysissa on hyödynnetty temaattista sisällönanalyysia (46). Analyysi on edennyt aineistojen läpikäymisen ja aihepiirin tutkimuksiin perehtymisen vuorovaikutuksessa (47). Aineiston analyysin ensimmäisessä vaiheessa kolme tutkijaa kartoittivat turvakotien seurantakyselyiden avovastauksista yleisimmät työntekijöiden esiin nostamat korona-aikaan liittyvät haasteet ja muutokset. Keskustelimme tuloksista koko ryhmän kesken ja luokittelimme aineiston kronologisesti kolmeen ryhmään, jotka jakautuvat 1) avun hakemiseen ja turvakotiin hakeutumiseen, 2) väkivaltatyön toteuttamiseen turvakotijakson aikana sekä 3) turvakotijakson jälkeiseen aikaan. Toisessa vaiheessa koodasimme fokusryhmäaineiston. Jäsensimme turvakotien ja väkivaltatyön avopalveluiden työntekijöiden fokusryhmähaastattelut seurantakyselyn tulosten pohjalta tekemäämme luokittelua hyödyntäen. Keskustelimme tuloksista koko ryhmän kesken. Analysoimme työntekijöiden fokusryhmähaastateeluissa esiin nostamia korona-ajan mukanaan tuomia muutoksia. Reflektoimme tuloksia aihepiiriä käsittelevän tutkimuskirjallisuuden valossa ja jäsensimme työntekijöiden kertomuksia avun hakemisen ja saamisen sekä väkivaltatyön toteuttamisen haasteista ja palveluohjauksesta turvakotijaksojen jälkeen.

Keskityimme analyysissa työntekijöiden näkemyksiin asiakkaiden tilanteista sekä väkivaltatyön käytännöistä (48). Palvelujärjestelmän ja väkivaltatyön käytäntöjen näkökulma mahdollistaa yksilöiden kokemusten ja rakenteiden välisten suhteen analysoimisen. Käytännöt ovat se konteksti, jossa väkivaltatyön arki ja siihen kohdistuvat haasteet tulevat näkyviksi. Käytännöt luovat myös kehyksen, jossa palveluja tarjotaan, asiakkaita kohdataan ja autetaan, ja joista asiakkaiden oletetaan palaavan takaisin omaan arkeen ja elämäänsä. Käytäntöjen tarkastelu auttaa muutosten ja palvelujärjestelmään kohdistuvien haasteiden jäsentämisessä ja tekee samalla näkyväksi väkivaltatyön katvealueita, muutosta edellyttäviä toimintatapoja ja haavoittuvissa asemissa olevia ryhmiä.

\section{TULOKSET}

\section{AVUN HAKEMISEN JA SAAMISEN HAASTEET}

Koronapandemiaan liittyvät liikkumisrajoitukset kodin ulkopuolella ovat rajanneet lähisuhdeväkivaltaa kokeneiden mahdollisuuksia hakea apua ja saada tukea omista sosiaalisista verkostoista. Myös lastensuojeluilmoitukset ovat tutkimusten mukaan vähentyneen, mikä viittaa lapsiin kohdistuvan väkivallan havaitsematta, kirjaamatta ja raportoimatta jäämiseen korona-aikana (9). Tilanne on lisännyt entisestään väkivaltatyön avopalveluiden ja turvakotien merkitystä avun tarjoajina. Turvakodit on pidetty koronapandemian aikana asiakkaille avoinna normaalisti, ja osassa turvakodeista on varattu yksittäisiä huoneita tai huoneistoja koronan riskiryhmään kuuluville ja 
koronaan altistuneille tai siihen sairastuneille. Muiden sosiaali- ja terveyspalveluiden saatavuudessa tapahtuneet muutokset ovat kuitenkin voineet johtaa tilanteisiin, joissa palveluohjaus turvakoteihin ja väkivaltatyön avopalveluihin on vähentynyt. Sekä turvakotien seurantakyselyiden avovastauksista että fokusryhmähaastatteluista käy ilmi, että yhteydenottoja asiakkailta on tullut korona-aikana moniin turvakoteihin normaalia vähemmän, vaikka tiedottamista turvakotien aukiolosta on lisätty.

TK3 30.3.2020: "Yhteydenottoja turvakotiin on ollut todella vähän. Mietitty, onko tarpeeksi tietoa palvelun saatavuudesta ja/tai pelätäänkö tartunnan saamista.”

Tutkimusaineistosta käy ilmi, että pelko koronan tarttumisesta itseen tai lapsiin on paikoitellen estänyt avun hakemista turvakodeista (ks. 39-40). Asiakasmäärien vähentyminen ja erityisesti lapsiperheiden ja lasten määrän laskeminen keväällä 2020 turvakodeissa nousi sekä kyselyn avovastauksissa että fokusryhmähaastatteluaineistoissa keskeiseksi teemaksi. Työntekijät kertoivat huolestaan erityisesti lähisuhdeväkivallalle altistuneiden ja sen kohteeksi joutuneiden lasten palveluiden piiristä häviämisestä.

R1O1: "Nyt on ollut niin hiljaista pitkään lapsiperheiden osalta kuitenki tässä turvakodissa, että semmosta huolta, ku ei sitä voi uskoo et väkivalta on loppunu, että aina ku ne elää kuitenki siellä perheen neljän seinän sisällä ja sieltä ei lähdetä syystä tai toisesta (...), vaikutti siihen korona vai mikä, että on kynnys lähtee. Että paljonko lapset elää kuitenkin hankalissa tilanteissa ja turvattomissa kodeissa."

Monet lähisuhdeväkivallan kohteena olleet ovat joutuneet pandemian aikana elämään väkivallantekijän valvonnan alla kodin ulkopuolisista sosiaalisista suhteista eristyksissä, mikä on hankaloittanut myös palvelujen piiriin hakeutumista ja avun saamista. Työntekijät pohtivat fokusryhmähaastatteluissa syitä yhteydenottojen vähenemiselle ja nostivat esille koronapandemian käyttämisen kumppanin ja lasten toiminnan kontrolloimisen välineenä sekä korona-aikana lisääntyneen pakottavan kontrollin (9-10).
R1O1: "Ei pysty välttämättä hakemaan sitä apua samalla tavalla, et jos koko ajan on paikalla koko perhe siinä nii, ei tule semmosta tilaisuutta et vaikka soittaa meille tai muuta." R3O2: "Kontrollointi, mitä mahdollisesti oli ollu kyllä aiemminki siinä parisuhteessa, muutti muotonsa ja siitä koronasta tuli väline jolla kontrolloidaan perheenjäsenen liikkumista ja toimintaa ylipäänsä.”

R3O1: "Korona nyt ehkä suo tässä tälläisen hyvän mehukkaan työkalun ja tälläsen osittain hyväksytyn keinon sitte käyttää sitä pakottavaa kontrollia. Et se ehkä nousee sieltä, se pakottava kontrolli on semmone mun mielestä edelleen Suomes aika heikosti osittain tunnistettu väkivallan muoto. Et nyt ehkä se on noussu sieltä ehkä paremmin esiin, koska tää korona tuo sen myös esiin.”

Etäyhteyksien lisääntyessä korona-aikana teknologian osuus kumppanin ja lasten valvomisessa on aineiston mukaan korostunut. Esimerkiksi liikkumisen seuraaminen teknologian avulla nousi esille useissa haastatteluissa. Etäpalveluihin siirtyminen korona-aikana on herättänyt väkivaltatyöntekijöiden keskuudessa kysymyksiä myös yhteyksien toimivuudesta ja luotettavuudesta. Haastatteluissa nousi esille esimerkiksi kommunikaatiovälineiden kontrollointi ja digitaalisen väkivallan muotojen kirjo, kuten puhelimen, sähköpostin ja sosiaalisen median tilien luvaton käyttö, salasanojen urkkiminen, kuvien luvaton levittäminen, puolison verkkotunnusten väärinkäyttäminen ja sen mahdollistama taloudellinen painostus.

Työntekijät mainitsivat haastatteluissa toistuvasti myös intersektionaaliset erot ja eriarvoisuudet asiakkaiden mahdollisuuksissa käyttää palveluja etäyhteyksin tilanteissa, joissa teknologiaa tai niiden käyttämiseen tarvittavia taitoja ei ole. Tämä asettaa ihmiset myös avun hakemisen ja saamisen suhteen eriarvoiseen asemaan ja on merkittävä riski etenkin haavoittuvissa asemissa olevien, kuten esimerkiksi lasten, ulkomaalaistaustaisten, ikääntyneiden sekä addiktioista ja erilaisista terveysongelmista kärsivien palvelujen toteutumiselle.

\section{VÄKIVALTATYÖN TOTEUTTAMISEN HAASTEET}

Korona-aikana erityisesti lapsiperheiden, lasten ja haavoittuvissa asemissa olevien asiakkaiden 
palveluiden toteuttamisessa on aineiston mukaan ollut haasteita. Kontaktien ja yhteistilojen välttäminen sekä ryhmätoiminnan ja yhteisöllisyyden vähentäminen ovat monissa tilanteissa merkinneet yhteisöllisyyteen nojaavista käytännöistä luopumista väkivaltatyössä. Aineistosta käy ilmi, että esimerkiksi vierailurajoitukset ovat korona-aikana estäneet isovanhempien tapaamisen ja lastenhoitoavun järjestämisen turvakodeissa. Myös yhteistilojen ja kontaktien välttämisen pyrkimys ja lapsiperheiden eristäminen omiin huoneisiinsa on tuonut lisähaasteita väkivaltatyölle.

TK29 6.4.2020: "Asiakastyöhön korona on vaikuttanut siten, että ryhmätoiminta on poistunut, mikä lisää etenkin lasten kohdalla levottomuutta ja myös aikuiset kaipaisivat virikkeitä. Osa asiakkaista pelkää turvallisuutensa ja terveytensä puolesta turvakodilla oloa ja miettivät olisiko parempi olla kuitenkin kotona."

Aineiston mukaan koronapandemia on myös rajoittanut palveluiden saatavuutta ja pakottanut kehittämään uusia tapaamisrajoituksiin ja etätyöskentelyyn paremmin sopivia käytäntöjä. Ohjeissa ja säännöissä on ollut alueellisia eroja, ja väkivaltatyön käytännöt ovat vaihdelleen alueellisten suositusten ja rajoitusten mukaan.

TK3 21.12.2020: "Asiakkaan kotikunta kieltäytyi ensin antamasta perhetyön palvelua turvakodille koronatilanteeseen liittyen. Turvakoti sijaitsee koronaviruksen leviämisalueella, perhetyöntekijät tulevat alueelta, missä korona on kiihtymisvaiheessa."

TK2 30.3.2020: "Jotkut lastensuojelun sosiaalityöntekijät eivät voi koronaepidemian ja oman työpaikkansa ohjeistuksen mukaisesti tulla tapaamaan perhettä turvakodille. Kotikunta ei myöskään voi myöntää perhetyötä / lastenhoitoapua perheelle turvakodille koronaepidemian vuoksi."

Aineistosta käy ilmi, että toimintakäytännöissä ja palvelujen saatavuudessa on huomattavia alueellisia eroja. Osa sosiaalityöntekijöiden tapaamisista siirtyi korona-aikana etänä toteutettaviksi. Etätapaamiset on koettu toimiviksi esimerkiksi tilanteissa, joissa ne nopeuttavat tapaamisten järjestämistä ja asioiden edistämistä.
R2O2: "Mun mielestä se on ollu ihan hyväki et paljon nopeemmin on järjestyny joku kiireellinen lastensuojelupalaveri, jos on voitu tehä nii että se on vaikka Teamsin välityksellä, et me ollaan asiakkaan kanssa turvakodilla ja sitte työntekijät Teamsissa."

Toisaalta etätyöskentely on työntekijöiden mukaan myös hidastanut avun saamista sekä asiakkaiden asioiden hoitoa. Kaikki kokoontumiset eivät ole mielekkäästi etätapaamisiksi siirrettävissä eikä kaikkia asioita ja tilanteita ei ole luontevaa käsitellä etäyhteyksien välityksellä, kuten alla olevasta esimerkistä käy ilmi.

R2O1: Työskentely on muuttunu kyllä paljonkin. Yks ihan hirvee kokemus oli 16 hengen lastensuojelupalaveri, jossa oli minä ja asiakas ja sit yks kunnan perhetyöntekijä fyysisesti turvakodilla, ja siis 16 asiantuntijaa eri puheluissa Teamsissa. Kaikki kertoivat sitten oman mielipiteensä tästä asiakkaan tilanteesta Teamsin kautta, ja se oli kyllä ihan todella huono kokemus."

Koronan mahdollistaman eristyksen ja kontrollin lisäksi keskeiseksi väkivaltatyön huoleksi aineistossa nousivat palveluiden saatavuuden ongelmat sekä kasvokkaisen vuorovaikutuksen väheneminen ja ryhmätoiminnan karsiutuminen työmenetelmistä. Asiakkaat ovat koronaan liittyvistä syistä aiempaa enemmän keskeyttäneet turvakotijaksoja. Korona-ajan näkyväksi tekemä vuorovaikutuksen ja vertaistuen vähentyminen on huomattu myös muissa tutkimuksissa merkittäväksi esteeksi yhteyden ja kuuluvuuden tunteen rakentumiselle sekä avun saamiselle ja siten koko väkivaltatyölle (49).

\section{PALVELUOHJAUS TURVAKOTIJAKSON JÄLKEEN}

Turvakotijakson jälkeisen palveluohjauksen ja tuen tarve nousi aineistoissa esille keskeisenä väkivaltatyön ongelmakohtana, joka kaipaa erityistä huomiota varsinkin korona-aikana. Turvakodista lähtemiseen ajoittuva vaihe osoittautuu erityisen haastavaksi tilanteissa, joissa läheisten suhteiden ylläpito on ollut rajoittunutta samalla kun palveluiden saatavuudessa on ollut puutteita.

R4O1: "Ehkä semmonen normaalist poikkeeva asia on sellanen, et kun aika usein ihmiset 
käyttää läheisverkostojaan, et he voi turvakotijaksonki jälkeen, vaikkei olisi uutta asuntoa, niin mennä vanhemmille, ystäville, sukulaisille, samoin kuin sen turvakotijakson aikana. On aika raskasta olla laitosolosuhteissa viikkokausia, niin monet voi käydä viikonloppusin esimerkiks sukulaisilla. Mut nyt kun nää sosiaaliset suhteet on poistettu, niin se aika tavalla hankaloittaa ihmisten elämää.”

R3O1: "Ongelmakohta sekä koronaolosuhteissa että normaalisti Suomessa on tää turvakotijakson jälkeinen tuki. Elikkä kun meil ei oo, kuten jossain muissa maissa esimerkiks on terapiapalveluita joita systemaattisesti pystytään tarjoon turvakotijakson jälkeen, nii tääl ei sellasta oo ja ihmiset tippuu aika tyhjän päälle. Kun he ovat kuitenkin usein traumatisoituneita, he ovat sen lisäks kriisitilanteessa, ja turvakotijakson aikana heitä kannatellaan aika intensiivisesti, ja todellisuudessa se heiän toimintakyky saattaa olla hyvin paljon heikompi kun miltä se ehkä sitten välillä näyttäytyy ja se tulee ilmi siinä ku he joutuukin lähteen yksin kotiin ja ei oo enää mitään palveluu tarjolla.”

Korona-ajan näkyväksi tekemä yksinäisyys ja eristys sekä palvelujärjestelmän aukot ja rakenteellisten ratkaisujen tarve osoittautuvat aineistossa merkittäviksi ongelmiksi myös turvakotijakson jälkeisenä aikana. Samaan aikaan tutkimukset osoittavat, että pandemian edetessä lähisuhdeväkivaltaa kokeneiden yksinäisyys on entisestään voimistunut (50). Laitosympäristöstä palatessaan väkivallan kohteena olleet voivat kokea niin voimakasta yksinäisyyttä, että paluu anteeksi anelevan ja muutosta vannovan väkivaltaisesti käyttäytyneen puolison luo saattaa tuntua yksin jäämistä houkuttelevammalta vaihtoehdolta (51-52). Myös pandemia-aikana on siten tärkeää toteuttaa interventioita, jotka vähentävät väkivallan osapuolten yksinäisyyttä, tuottavat liittymisen ja kuulumisen kokemuksia ja vähentävät lähisuhdeväkivaltaa kokeneiden häpeää ja eristäytymistä. Samalla ne edistävät väkivaltatyön käytäntöjen ja rakenteiden kehittämistä sekä väkivallan syklien ja jatkumoiden katkaisemista.

\section{POHDINTA}

Väkivaltatyöntekijät kertovat huolen asiakkaista lisääntyneen korona-aikana. Pandemiaan liittyvät rajoitukset ja suositukset sekä pelko tartunnan saamisesta ovat vaikeuttaneet avun hakemista ja väkivaltatyön palveluiden toteuttamista $(50,53)$. Lisäksi kotiin eristäytymisen mahdollistama pakottava kontrolli, kodin ulkopuolisten kohtaamisten ja yhteisöllisen toiminnan puute sekä työkäytäntöjen muutokset nousivat aineistossa keskeisiksi väkivaltatyön organisoimisen haasteiksi. Myös digitaalisen ja taloudellisen väkivallan eri muotojen esille nouseminen korona-aikana herättivät huolta sekä seurantakyselyssä että fokusryhmähaastatteluissa.

Haavoittuvien ryhmien, kuten väkivaltaa kokeneiden naisten, lasten ja ulkomaalaistaustaisten palveluiden ulkopuolelle jäämisellä on kauaskantoiset vaikutukset yksilöiden, perheiden ja yhteisöjen terveyteen ja hyvinvointiin (54-55). Se vaikuttaa oleellisesti myös lähisuhdeväkivallan tunnistamisen, siihen puuttumisen ja avun saamisen mahdollisuuksiin. Kun väkivalta jää havaitsematta, se ei tule dokumentoiduksi eikä kirjatuksi tietokantoihin. Väkivallan kirjaamisella - ja kirjaamatta jättämisellä - on kauaskantoisia seurauksia nyky-yhteiskunnassa, jossa symboliset ja sanalliset dokumentit ovat merkittäviä todellisuuden tuottajia. Dokumentoimattomat ilmiöt häviävät näkyvistä sekä ilmiöinä että organisatorisen muistin osina (56). Tämä vaikuttaa paitsi palvelujen järjestämistä koskeviin rakenteellisiin ratkaisuihin, myös yksittäisten ihmisten ja yhteisöjen näkemyksiin ja käsityksiin väkivaltailmiön vakavuudesta, yleisyydestä ja sen merkittävyydestä terveydellisenä ongelmana, inhimillisen kärsimyksen tuottajana sekä hyvinvoinnin ja kestävän kehityksen uhkana.

Palvelujärjestelmän ja väkivaltatyön käytäntöjen kehittäminen edellyttää sekä rakenteellisen eriarvoisuuden että inhimillisen haavoittuvuuden tunnistamista ja niiden vaikutusten huomioimista (57). Koronaan liittyvä kotiin eristäytyminen on tutkimusten mukaan lisännyt yksinäisyyttä ja yksinäisyyden pelkoa, ja hidastanut siten myös omasta kodista ja väkivaltaisesta suhteesta irrottautumista (49). Erityisen haavoittuvaan asemaan eristys on asettanut useita eriarvoistavia ja alistavia käytäntöjä ja rakenteita kohtaavat (5859). Korona-aika on tehnyt näkyväksi väkivallan sukupuolistuneisuuden lisäksi erityisesti lasten ja lapsiperheiden palveluiden haavoittuvuuden, lähisuhdeväkivaltaa kokeneiden yksinäisyyden sekä osallisuuden, liittymisen ja kuulumisen ko- 
kemusten tärkeyden ja merkityksen väkivallasta irrottautumisessa ja siitä toipumisessa.

Yhteisöllisyyden ja tukiverkostojen puute ovat asettaneet haasteita myös väkivaltatyön käytännöille. Palveluiden saavutettavuuden sekä lähisuhdeväkivallan tunnistamisen ja puheeksi ottamisen merkitys sosiaali- ja terveyspalveluissa korostuvat tilanteissa, joissa pakottava kontrolli estää avun hakemista ja vahvistaa sosiaalisista suhteista eristäytymistä. Sosiaali- ja terveydenhuollon sekä kasvatusalan ammattilaiset ja poliisi voisivat omalla toiminnallaan olla avainasemassa väkivallan muotojen tunnistamisessa ja niihin puuttumisessa. Tutkimusten mukaan ilmiöön liittyvissä tiedoissa, väkivallan kohtaamisen valmiuksissa, väkivaltatyön osaamisessa sekä moniammatillisen yhteistyön organisoimisessa on kuitenkin edelleen puutteita $(17,60)$. Tämä johtuu osaltaan lähisuhdeväkivaltaa käsittelevien opintojen puuttumisesta tutkintoihin valmistavista koulutuksista Suomessa. Eri alojen asiantuntijoiden ja ammattilaisten väkivaltakoulutukselle on siten ilmeinen tarve.

Lähisuhdeväkivaltaan haetaan yleensä apua vasta pitkän ajan kuluttua väkivallan alkamisesta. Korona-aikana tapahtunut väkivalta saattaa siten näkyä palvelujärjestelmän kuormituksena vielä vuosien päästä. Poikkeustila jatkuu tältä osin, ja väkivaltatyön haasteiden tunnistamiselle sekä palvelujärjestelmän kehittämiselle on suuri tarve. Tieto siitä, miten koronatilanne on vaikuttanut avun hakemiseen ja palveluihin on tärkeää väkivaltainterventioiden kohdentamiseksi, tuen ja palveluiden saatavuuden turvaamiseksi, kotona tapahtuvan väkivallan ja sen mukanaan tuoman inhimillisen kärsimyksen ja kuormituksen vähentämiseksi sekä tasa-arvon ja kestävän kehityksen edistämiseksi.

\section{RAHOITTAJAT:}

Eduskunnan myöntämä lisämääräraha koronaepidemian yhteiskunnallisten vaikutusten tutkimiseen.

\section{KIRJOITTAJIEN KONTRIBUUTIOT:}

Husso on toiminut vastuukirjoittajana, osallistunut tutkimuksen suunnitteluun, haastattelun laatimiseen, aineiston keräämiseen ja analysoimiseen ja vastannut artikkelin kaikkien osien kirjoittamisesta, kokonaisuudesta ja viimeistelystä. Hyväri on osallistunut kyselyn analyysiin ja luokitteluun, haastatteluaineiston keräämiseen, koodaamiseen ja analysoimiseen sekä johdannon ja analyysin kirjoittamiseen. Kaittila on osallistunut tutkimuksen suunnitteluun, haastattelun laatimiseen, haastatteluaineiston keräämiseen ja analysoimiseen, johdannon ja menetelmäosuuden kirjoittamiseen sekä käsikirjoituksen kommentointiin ja viimeistelyyn. Hietamäki on osallistunut tutkimuksen suunnitteluun, haastattelun ja kyselyn laatimiseen sekä aineiston keräämiseen ja analysoimiseen, laatinut kuvion ja osallistunut johdannon sekä taustoituksen kirjoittamiseen. Karhinen-Soppi ja Kekkonen ovat osallistuneet kyselyaineiston analysoimiseen ja luokitteluun, haastatteluaineiston keräämiseen, koodaamiseen ja analysoimiseen sekä käsikirjoituksen luonnosteluun ja lähdeluettelon viimeistelyyn. Tuominen on osallistunut tutkimuksen suunnitteluun, haastattelun laatimiseen, aineiston analyysiin ja johdannon kirjoittamiseen sekä käsikirjoituksen kommentointiin.

Husso, M., Hyväri, E., Kaittila, A., Hietamäki, J., Karhinen-Soppi, A., Kekkonen, O., \& Tuominen, J. Home, Covid and Control. The challenges of getting help for domestic violence during the COVID-19 pandemic. Sosiaalilääketieteellinen aikakauslehti - Journal of Social Medicine 202 I : 58: 349-360.

Domestic violence is a serious global social and health problem as well as a human rights issue. Studies show that intimate partner violence has typically increased in the context of social crises such as pandemics and natural disasters. The prevalence of domestic violence has also increased during the COVID-19 pandemic. The United Nations has identified violence against women and children as a shadow pandemic of COVID-19. Recommendations and restrictions to avoid social contact have been justified when preventing the spread of the virus. However, social isolation has put victims of domestic violence in a more vulnerable position.

This article explores the challenges of seeking and receiving help during the COVID-19 pandemic. The data consist of interviews with shelter employees from $1 / 2020$ to $2 / 2021$ as well as shelters' weekly reports that consider the effects of COVID-19 on shelter work and customer 
situations. The results show that, during the lockdown, victims of violence have lived under the control and supervision of the perpetrator without access to assistance and support services. Although the amount of domestic violence during the COVID-19 pandemic has increased, the number of people coming to shelters has decreased in Finland since the pandemic began. The threats and fears associated with the virus, as well as the isolation related to the restrictions, the possibility of coercive control, and forms of digital violence pose significant challenges for both seeking help and sheltering provision. Knowledge of how the pandemic affects experiences of violence, services, and opportunities to provide and receive services is vital for targeting interventions and ensuring access to support and services.

Keywords: COVID-19, domestic violence, social services, welfare state

$$
\begin{array}{cc}
\text { Saapunut } & (23.03 .2021) \\
\text { Hyväksytty } & (02.09 .2021)
\end{array}
$$

\section{LÄHTEET}

(1) Heiskanen M, Piispa M. Väkivallan kustannukset kunnassa. Sosiaali- ja terveysministeriön selvityksiä 2002:6. Helsinki: Sosiaali- ja terveysministeriö; 2002.

(2) Hughes K, Bellis M, Hardcastle K, ym. The effect of multiple adverse childhood experiences on health: a systematic review and meta-analysis. The Lancet Public Health 2017;2:e356-e366. doi: 10.1016/S2468-2667(17)30118-4

(3) Lehti M. Henkirikoskatsaus 2019. Luettu 22.2.2021. http://urn.fi/ URN:ISBN:978-951-51-0665-0

(4) Anastario M, Shehab N, Lawry L. Increased gender-based violence among women internally displaced in Mississippi 2 years post-hurricane Katrina. Disaster Medicine and Public Health Preparedness 2009;3:18-26. doi: 10.1097/DMP.0b013e3181979c32

(5) Peterman A, O’Donnell M, Palermo T. COVID-19 and violence against women and children. what have we learned so far? Washington (DC): Center for Global Development; 2020. Luettu 20.02.2021. https:// www.cgdev.org/sites/default/files/covid-andviolence-against-women-and-children-what-wehave-learned.pdf

(6) Rezaeian, M. The association between natural disasters and violence: A systematic review of the literature and a call for more epidemiological studies. Journal of Research in Medical Science 2013;18:1103-1107.

(7) Schumacher JA, Coffey SF, Norris $\mathrm{FH}, \mathrm{ym}$. Intimate partner violence and Hurricane Katrina: Predictors and associated mental health outcomes. Violence and victims 2010;25: 588-603. doi: 10.1891/0886-6708.25.5.588

(8) Zahran S, Shelley O'Connor T, Peek L, ym. Natural disasters and social order: modeling crime outcomes in Florida. Int J Mass Emerg Disasters 2009;27:26-52.

(9) Campbell, AM. An increasing risk of family violence during the Covid-19 pandemic: Strengthening community collaborations to save lives. Forensic Science

International: Reports 2020;2:100089. doi: 10.1016/j.fsir.2020.100089

(10) López de Aguileta G, Torras-Gómez E. Editorial: Contributions from Social Sciences to COVID-19 Pandemic. International and Multidisciplinary Journal of Social Sciences 2020;9:102-106. doi: 10.17583/rimcis.2020.6160

(11) Piquero AR, Riddell JR, Bishopp SA, ym. Staying Home, Staying Safe? A ShortTerm Analysis of COVID-19 on Dallas Domestic Violence. American Journal of Criminal Justice 2020;45:601-635. doi: 10.1007/s12103-020-09531-7

(12) Storz, MA. Child abuse: A hidden crisis during covid-19 quarantine. Journal of Paediatrics and Child Health 2020;56:990-991. doi: 10.1111/jpc.14919

(13) Hamadani JD, Hasan, MI, Baldi AJ, ym. Immediate impact of stay-at-home orders to control COVID-19 transmission on socioeconomic conditions, food insecurity, mental health, and intimate partner violence in Bangladeshi women and their families: an interrupted time series. The Lancet Global health 2020;10:e1380-e1389. doi: 10.1016/S2214-109X(20)30366-1

(14) Eige. The Covid-19 pandemic and intimate partner violence against women in the EU. Luxembourg: Publications Office of the European Union; 2021. doi: 10.2839/959007.

(15) Hoseinnezhad S Z, Elyasi F, Shahhosseini Z. A Rapid Review on Domestic Violence as a Silent Consequence in Corona Time: A Double Pandemic. European Journal of Environment and Public Health 2021;5:em0062. doi: $10.29333 /$ jeph/8577

(16) UN Women. COVID-19 and ending violence against women and girls. 2020. Luettu 1.1.2021. https://www.unwomen.org/en/digital-library/ publications/2020/04/issue-brief-covid-19-andending-violence-against-women-and-girls

(17) Husso M, Karkulehto M, Saresma T, ym. Ideological, institutional and affective practices of interpersonal violence. Kirjassa: Husso 
M, Karkulehto S, Saresma T, ym. (toim.)

Gender, Violence and Affect; Interpersonal, Institutional and Ideological Practices. Cham, Switzerland: Palgrave Macmillan; 2021, 3-26. doi: 10.1007/978-3-030-56930-3

(18) European Union Agency for Fundamental Rights (FRA). Violence against women: An EU-wide survey. 2014. Luettu 1.1.2021. https://fra.europa. eu/en/publication/2014/violence-against-womeneu-wide-survey-main-results-report

(19) Tilastokeskus. Aikuisista perhe- ja lähisuhdeväkivallan uhreista 76,8 prosenttia naisia. 2.6.2020 Luettu 1.1.2021. https://www.stat.fi/til/ rpk/2019/15/rpk_2019_15_2020-06-02_tie_001_ fi.html

(20) Wright EN, Anderson J, Phillips K, ym. HelpSeeking and Barriers to Care in Intimate Partner Sexual Violence: A Systematic Review. Trauma, Violence \& abuse 2021;1-19. doi: $10.1177 / 1524838021998305$

(21) Hietamäki J, Kaipanen S, Seppälä T, ym. Nollalinjan puhelinpalvelu auttaa lähisuhdeväkivaltaa kokevia. Tulokset, arviointi ja suositukset. Raportti 10/2020. Helsinki: Terveyden ja hyvinvoinnin laitos; 2020. http://urn.fi/URN:ISBN:978-952-343-545-2

(22) Husso M, Hirvonen M, Notko M. From rejection to understanding: Towards a synthetic approach to interpersonal violence. Kirjassa: Husso M, Virkki T, Notko M, ym. (toim.) Interpersonal violence: Differences and Connections. Routledge; 2019; 2017; 2016, 1-14. doi: 10.4324/9781315628509

(23) Nikander E, Notko M, Husso M. Lähisuhdeväkivaltaan puuttuminen ja ammattilaisten koulutus sosiaali- ja terveydenhuollossa ja poliisissa: EPRAS-hankkeen arviointi. Raportti nro 13/2019. Helsinki: Terveyden ja hyvinvoinnin laitos; 2019. http://urn.fi/ URN:ISBN:978-952-343-369-4

(24) Piippo S, Husso M, Hirvonen P, ym. Institutional and affective practices of domestic violence interventions in social work: Malignant positioning of the victims. Kirjassa: Husso M, Karkulehto S, Saresma T, Laitila A, Eilola J, Siltala H. (toim.) Violence, Gender and Affect: Interpersonal, Institutional and Ideological Practices. Cham, Switzerland: Palgrave Macmillan; 2021, 113-133. doi: 10.1007/978-3-030-56930-3

(25) Virkki T, Husso M, Notko M, ym. Lähisuhdeväkivallan kehystäminen erikoissairaanhoidossa: puuttumisen ja muutoksen mahdollisuudet. Sosiaalilääk Aikak 2011;48:280-298.

(26) Husso M, Notko M, Virkki T, ym. Domestic violence interventions in social and health care settings: Challenges of temporary projects and short-term solutions. Journal of Interpersonal Violence. 2020. doi: $10.1177 / 0886260519898438$

(27) Lavis V, Horrocks C, Kelly N, ym. Domestic violence and health care: opening pandora's box - challenges and dilemmas. Feminism \& Psychology 2005;15(4):441-60. doi: 10.1177/0959-353505057618
(28) Fagerlund M, Houtsonen J, Notko M, ym. Conceptualising violence in close relationships: discrepancies between police conceptions and the letter of the law in Finland. European Journal on Criminal Policy and Research. 2020. doi: 10.1007/s10610-020-09448-1

(29) Bildjuschkin K, Ewalds H, Hietamäki J, ym. Väkivaltakäsitteiden sanasto. Terveyden ja hyvinvoinnin laitos; 2020. http://urn.fi/ URN:ISBN:978-952-343-211-6

(30) Turvakotilaki. Laki valtion varoista maksettavasta korvauksesta turvakotipalvelun tuottajalle 30.12.2014/1354. https://www.finlex. fi/fi/laki/ajantasa/2014/20141354

(31) Turvakotipalvelut 2019. Tilastoraportti 17/2020. Helsinki: Terveyden ja hyvinvoinnin laitos. Luettu 20.02.2021. http://urn.fi/URN:NBN:fi-fe2020060139895

(32) Ensi- ja turvakotien liitto. Työmme lukuina. Luettu 27.8.2021. https://ensijaturvakotienliitto. fi/vaikuta-yhteiskuntaan/tyomme lukuina/\#vakivaltatyo

(33) Peltonen J, Nipuli S. Lasten määrä laski turvakodeissa viime vuonna. THL Uutinen 15.2.2021. Luettu 20.02.2021. https://thl.fi/fi/-/ lasten-maara-laski-turvakodeissa-viime-vuonna

(34) Turvakotipalvelut 2020. Tilastoraportti 17/2021. Helsinki: Terveyden ja hyvinvoinnin laitos. Luettu 27.8.2021. http://urn.fi/URN:NBN:fi-fe2021060132533

(35) Husso M. Parisuhdeväkivalta. Lyötyjen aika ja tila. Tampere: Vastapaino; 2003

(36) Kaittila A. Parisuhdeväkivaltaa kokeneet naiset avunhakijoina. Kirjassa: Niemi J, Kainulainen H, Honkatukia P. (toim.) Sukupuolistunut väkivalta - oikeudellinen ja sosiaalinen ongelma. Vastapaino; 2017.

(37) Goh KK, Lu M, Jou S. Impact of COVID-19 pandemic: Social distancing and the vulnerability to domestic violence. Psychiatry and clinical neurosciences 2020;74(11):612-613. doi: $10.1111 /$ pcn. 13130

(38) Wilke NG, Howard AH, Pop D. Datainformed recommendations for services providers working with vulnerable children and families during the COVID-19 pandemic. Child Abuse \& Neglect 2020;110(Pt 2). doi: 10.1016/j.chiabu.2020.1046

(39) Morgan A, Boxall H. Social isolation, time spent at home, financial stress and domestic violence during the COVID-19 pandemic. Trends and Issues in crime and criminal justice 2020; 609:1-18. doi: $10.52922 /$ ti04855

(40) Jarnecke AM, Flanagan JC. Staying safe during COVID-19: How a pandemic can escalate risk for intimate partner violence and what can be done to provide individuals with resources and support. Psychol Trauma 2020;12. doi: $10.1037 /$ tra0000688.

(41) Fanslow JL, Robinson EM. Help-seeking behaviours and reasons for help seeking reported by a representative sample of women victims of intimate partner violence in New Zealand. 
Journal of Interpersonal Violence 2010; 25:929_ 951. doi: 10.1177/0886260509336963

(42) Women in Personal Life. New York: Oxford University Press; 2009.

(43) Markovà I, Linell P, Grossen M, Orvig A S. Dialogue in focus groups: Exploring socially shared knowledge. London: Equinox; 2007.

(44) Valtonen, A. Ryhmäkeskustelut - millainen metodi? Kirjassa: Ruusuvuori J, Tiittula L. (toim.) Haastattelu: tutkimus, tilanteet ja vuorovaikutus. Tampere: Vastapaino; 2008, 223-241.

(45) Mäntyranta T, Kaila M. Fokusryhmähaastattelu laadullisen tutkimuksen menetelmänä lääketieteessä. Duodecim, 2008:124:1507-1513.

(46) Silverman D. Interpreting qualitative data: methods for analysing talk, text and interaction. London: Sage; 2006.

(47) Tuomi J, Sarajärvi A. Laadullinen tutkimus ja sisällönanalyysi. Helsinki: Tammi; 2002.

(48) Gherardi S. Organizational knowledge: the texture of workplace learning. Oxford: Blackwell; 2006.

(49) Lev Uden Vold. Gender and the COVID-19 outbreak: a literature review of coronavirusrelated knowledge and practices. Denmark as a case study. University of Copenhagen: Coordination for gender studies 2020. Luettu: 1.1.2021. https://www.soc.ku.dk/ instituttet/nyheder_/behov-for-fokus-paacoronaepidemiens-koensforskelle/Gender_Covid_19_outbreak_.pdf

(50) Goodman LA, Epstein D. Loneliness and the COVID-19 pandemic: implications for intimate partner violence survivors. J Fam Viol 2020;1-8. doi: 10.1007/s10896-020-00215-8

(51) Fisher EM, Stylianou, AM. To Stay or to Leave: Factors Influencing Victims' Decisions to Stay or Leave a Domestic Violence Emergency Shelter. Article first published online April 28, 2016; Journal of Interpersonal Violence 2019;34:785811. doi: $10.1177 / 0886260516645816$

(52) Eisikovits Z, Band-Winterstein T. Dimensions of Suffering among Old and Young Battered Women. J Fam Viol 2015;30:49-62. doi: 10.1007/s10896-014-9655-9

(53) Women's Aid. A Perfect Storm The Impact of the Covid-19 Pandemic on Domestic Abuse Survivors and the Services Supporting Them. Bristol: Women's Aid;2020. Luettu 22.02.2021. https://www.womensaid.org.uk/a-perfectstorm-the-impact-of-the-covid-19-pandemicon-domestic-abuse-survivors-and-the-servicessupporting-them/

(54) Campbell J C. Health consequences of intimate partner violence. Lancet 2002;359:1331-1336. doi: 10.1016/S0140-6736(02)08336-8

(55) Pournaghash-Tehrani S, Feizabadi Z. Predictability of Physical and Psychological Violence by Early Adverse Childhood Experiences. J Fam Viol 2009;24:417-422. doi: 10.1007/s10896-009-9245-4

(56) Ferraris M. Documentality: Why it is necessary to leave traces. New York: Fordham University Press; 2013.
(57) Näre S, Ronkainen S. Paljastettu intiimi: sukupuolistuneen väkivallan dynamiikkaa. Rovaniemi: Lapin yliopistokustannus; 2008.

(58) Dasgupta J, Schaaf M, Contractor SQ, ym. Axes of alienation: applying an intersectional lens on the social contract during the pandemic response to protect sexual and reproductive rights and health. International Journal for Equity in Health 2020;19(1):130-130. doi: 10.1186/s12939-020-01245-

(59) Usher K, Bhullar N, Durkin J, ym. Family violence and COVID-19: Increased vulnerability and reduced options for support. International Journal of Mental Health Nursing 2020;29(4):549-52. doi: 10.1111/inm.12735

(60) Notko M, Husso M, Piippo S, ym. Intervening in domestic violence: interprofessional collaboration among social and health care professionals and the police. Journal of Interprofessional Care 2021. doi: 10.1080/13561820.2021.1876645

\section{Marita Husso}

YTT, Tenure track -professori

Tampereen yliopisto

Yhteiskuntatieteiden tiedekunta

\section{ELLI HYVÄRI}

YTK, tutkimusavustaja

Tampereen yliopisto

Yhteiskuntatieteiden tiedekunta

\section{ANNIINA KaITTILA}

YTT, erikoistutkija

Turun yliopisto

Yhteiskuntatieteellinen tiedekunta

JoHanna HietamäKI

YTT, erikoistutkija

Terveyden ja byvinvoinnin laitos

ANU KaRHINEN-SoppI

YTM, tutkimuskoordinaattori

Tampereen yliopisto

Yhteiskuntatieteiden tiedekunta

Outi KeKKonen

YTK, tutkimusavustaja

Tampereen yliopisto

Yhteiskuntatieteiden tiedekunta

JARNO TUOMINEN

PsM, erikoistutkija

Turun yliopisto

Yhteiskuntatieteellinen tiedekunta 